\title{
Students' Perception on Pre-reading Activities in Basic Reading II Class of the English Language Education Study Program of Sanata Dharma University
}

\author{
Vindy Cahya Ekaningrum \\ Carla Sih Prabandari \\ Sanata Dharma University
}

\section{Abstract}

In a reading classroom, the teacher needs to prepare the students since the beginning of a reading process. The teachers can create pre-reading activities before the students start to read. The pre-reading activities are essential to activate students' background knowledge and to develop the students' motivation. They will create an effective reading classroom. The students' perception on the teaching techniques implemented by the teacher is important. The students' perception on the teacher instruction shows whether the teaching techniques meet the students' need or not. Because of this reason, the researcher wants to find out the varieties of pre-reading activities used by the teacher and the students' perception on the implementation of the prereading activities. There were two problem formulations in this study: 1) What kinds of prereading activities that are used by Basic Reading II teacher in the English Language Education Study Program of Sanata Dharma University? 2) How is the students' perception on pre-reading activities used by the teacher?

This research was a survey research. In gathering the data, there were two instruments used in this research. They were interview and questionnaire. The interview was done by interviewing the teacher of Basic Reading II Class. The interview was used to answer the first research question about the varieties of pre-reading activities in Basic Reading II class. Then, the researcher distributed the questionnaire to 56 students of Basic Reading II class. The questionnaire was used to answer the second research question about the students' perception on pre-reading activities used by the teacher.

The result of this research showed that brainstorming, pre-teaching vocabulary, prequestioning, visual aids, and KWL strategy were the varieties of pre-reading activities used by the teacher. There were two different implementation of pre-teaching vocabulary. There were also two activities combined together, they were the use of visual aids and KWL strategy. The students had positive perception on the implementation of pre-reading activities in Basic Reading II Class. The students got many advantages from the implementation of pre-reading activities which help them to understand reading materials.

Keywords: perception, pre-reading activities, Basic Reading II class

\section{A. INTRODUCTION}

In a reading classroom, the teacher has a responsibility to plan the instructions which make the students experience the satisfaction of learning from the text (Vacca and Vacca, 1989). The teachers need to help the students get along with the text since the beginning of the reading process. The teachers can prepare the students before they start to read. "Prereading activities are especially important, as they prepare students to read a selection." (Armbruster \& Osborn, 2002, p. 85). Colorado (2008) states, "Prereading activities can engage student interest, activate prior knowledge, or preteach potentially difficult concepts and vocabulary" (p.1). In the pre-reading 
stage, activating the students' background knowledge is essential. Carrel states that the reader's failure to activate an appropriate schema in reading may result in various degrees of non-comprehension (as cited in Navarro, 2008). Moreover, developing students' motivation through pre-reading activities is no less important. According to Colorado (2008) in the prereading stage, the teachers should create motivating activities that interest students in the text and motivate them to read. Marinak and Gambrell (2009) state, "Research confirms that student motivation is a key factor in successful reading" (p.1). It means that the students who have motivation to read will perform well in the reading classroom. Variations in teaching reading are necessary. Baghaei and Riasati (2013) state, "Creative teaching employs flexible and appropriate techniques so that the classes become fun and interesting" (p.1).

The varieties of pre-reading activities are implemented in Basic Reading II class in the English Language Education Study Program of Sanata Dharma University academic year 2013/2014. The teacher starts the reading class with the varieties of prereading activities before giving the students the reading materials. Regarding to the number of the pre reading activities that are used by the teacher, the researcher wants to conduct a research on what kinds of pre reading activities used by the teacher of Basic Reading II class. Moreover, the students may have various views, such as whether they are effective or not to help them to achieve their reading comprehension. The students' perception on the teaching techniques implemented by the teacher is important. If the students have positive perception, it shows that the teachers' instruction meet the students' need. Considering these backgrounds, the researcher would like to discover what kinds of pre-reading activities are used by the teacher in Basic Reading II class and the students' perception on the use of pre-reading activities.

This research tries to answer two research problems which are formulated as follows:

1. What kinds of pre-reading activities are used by Basic Reading II teacher in the English Language Education Study Program of Sanata Dharma University?

2. How is the students' perception on the pre-reading activities used by the teacher?

\section{B. REVIEW OF RELATED LITERATURE}

\section{Pre-reading Activities}

Pre-reading activities include the activities and discussions before reading which reduce the uncertainty that the students bring to the texts (Vacca and Vacca, 1989). Pre-reading activities are able to activate the students' background knowledge. Nunan (2003) states that all experiences which are accumulated and brought to the reading texts belong to the readers' background knowledge. Prereading activities help the students to relate their background knowledge and the new information which they find in the text (Ajideh, 2006). The teachers have the important roles to provide effective instructions in the pre-reading stage of the reading classroom. Vacca and Vacca (1989) address four purposes of prereading activities which teacher applies in pre-reading activities. They are motivating readers, building and activating background knowledge, introducing key vocabulary and concepts, and developing awareness of the task demands of the assignment and the strategies necessary for effective learning. The teachers are able to select the appropriate pre-reading activity related 
to the reading text. Moreover, the teachers are also able to combine some of the pre-reading activities in the prereading stage. Hedge (2000) says, "A range of activity types are possible at this stage and teachers can select or combine from a repertoire, ..." (p. 210). This research addressed the varieties of prereading activities as follows.

\section{a. Brainstorming}

In the brainstorming activity, the students need to mention words and concepts which have associations with the keyword provided by the teacher. Wallace (2003) states, "This may take the form of giving the class a particular key word or key concept, or it may be a newspaper headline or book title" (p.91). Wallace (2003) claims that there are three advantages of brainstorming. They are requires little teacher preparation, allows learners considerable freedom to bring their own prior knowledge and opinions to bear on particular use, and can involve a whole class.

\section{b. Pre-Teaching Vocabulary}

Pre-teaching vocabulary is helpful for the students in achieving their reading comprehension. According to Mihara (2011), pre-teaching vocabulary may help address unfamiliar words or phrases that can interfere with students' comprehension. There is a correlation between vocabulary mastery and reading comprehension (Armbruster and Osborn, 2002. If the students have good vocabulary mastery of the text, they will have better understanding of the text.

\section{c. Pre-Questioning}

Another pre-reading activity which can be implemented before reading is giving questions related to the text. Ajideh (2006) says, "Some pre-reading activities simply consist of questions to which the reader is required to find answers from the text" (p. 6). Besides providing the prequestions for the students, the teacher can ask them to create their own questions related to the reading text. Vacca and Vacca (1989) state, "Teaching students to generate their own questions about material to be read is one of the major instructional goals of prereading preparation." (p. 146).

\section{d. Visual Aids}

The use of visual materials in prereading activities can help the students in activating or building their background knowledge. Navarro (2008) says visuals have an important role in building schema for English language learners. The material can be in the form of pictures, videos, or others. Porter (n.d) states, "Pictures and other visual material can activate a students' prior knowledge.

\section{e. Conceptual Related Readings}

Activating the students' background knowledge and building their frame of reference can also be achieved by giving multiple texts with the same topic to the students. Vacca and Vacca (1989) mention that the use of the multiple texts is a strategy which is able to build multiple perspectives and background knowledge for the concept development. There are many sources related can help the students to develop concepts of what they read. They are multiple textbooks, popular books, pamphlets, or magazine.

\section{f. Previews}

Previews provide the students with a frame of reference in which to understand a new material (Vacca\&Vacca, 1989).To construct a preview, Vacca and Vacca (1989) address some steps. The teacher can start with a series of short statements and one or more questions which spark interest, provide a link between a familiar topic and the topic of the story, and encourage students to 
actively reflect upon the theme. The teachers can also provide a synopsis of the story which includes key elements in the story structure (without signaling the resolution or outcome of the plot). Moreover, the teachers can define several key terms within the context of the preview passage.

\section{g. KWL Strategy}

There is a technique named KWL strategy. Farrel (2003) states, "One method that will encourage students to have a personal connection to a reading assignment is the K-W-L" (p.13). The abbreviation stands for "What do I Know?", "What do I Want to know?", and, "What have I Learned?".Farrel (2003) states that these questions will activate the students' prior knowledge and motivates them to find the answer from the text. Vacca and Vacca (1989) state that the students can ask two of the most appropriate questions about reading selection. By asking what the students need to know helps them to activate their background knowledge, make prediction on what they want to read and find out the purpose they read the text. Then, by asking what students have already known of the text helps them to search their experiences and knowledge related to the text.

\section{Perception}

According to McShane and Glinow (2005), "Perception is the process of receiving information about and making sense of the world around us" (p. 76). It is stated that in the process of perception, somebody will receive information from their surroundings. Then, the person will give meaning on the information received. Therefore, the process of perception makes us able to interpret information around us and understand the information. People will give their responses to stimuli from the surroundings. McShane and Glinow (2005) state, "The resulting perceptions influence our emotions and behavior toward those objects, people, and events" (p. 77). Therefore, people's perception about something will influence the way they response about something, whether it is positive or negative.

The research of the students' perception on pre-reading activities is worth doing to know the students perception on the teaching instructions implemented by the teacher. If the students perceived positively toward the teaching techniques used by the teacher, they will think that the teaching techniques are helpful and important for them to be successful in the reading class. The students will show their interest to the pre-reading activities. On the other hand, if the students respond to the instructions negatively, the students are not interested to the pre-reading activities. The students' perception on pre-reading activities which are based on their experiences will affect their way of thinking or interpreting the pre-reading activities implemented by the teacher.

\section{METHODOLOGY}

The researcher used survey research to get the information. "In survey research, investigators ask questions about people's beliefs, opinions, characteristics, and behavior" (Ary, Jacobs, \& Sorensen, 2010, p.372). The researcher asked questions about student's opinion on the pre reading activities in Basic Reading II class of Sanata Dharma University. Through survey research, the researcher was able to explore and analyze the characteristics of pre-reading activities in Basic Reading II class of the English Language Education Study Program of Sanata Dharma University. Moreover, the researcher could explore and analyze the 
students' perception on the implementation of pre-reading activities.

The subjects of this research were the students of Basic Reading II classes in the academic year 2013/2014 and the teacher of the Basic Reading II classes where the questionnaire distributed. The students were chosen as the primary participants. The researcher took 56 students from the Basic Reading II classes, namely class $C$ and $D$. The researcher conducted the research in April 2014.

The researcher conducted the interview to the teacher face to face. Through following the interview guidelines, the researcher was going to find out the implementation of prereading activities that the teacher applied. The researcher would find the information of the varieties of prereading activities used by the teacher, the reason of the choices, and the effect for the students. The researcher also distributed the questionnaire to the students in two Basic Reading II classes. The purposes were to explore students' perception on the implementation of prereading activities.

From the interview result, the researcher made a summary based on the data collection. After that, the researcher analyzed the data and drew a conclusion based on the data which is obtained. Next, the researcher calculated the students' answer from the questionnaire. Each question statement of the data was analyzed. The researcher constructed rating scale. The data obtained and the numbers of the respondents were calculated.

\section{RESEARCH RESULTS AND DISCUSSION}

\section{The Varieties of Pre-reading Activities Implementation in Basic Reading II Class}

From the interview result, the researcher analyzed the pre-reading activities used by the teacher as follows.

\section{a. Brainstorming}

The first type of pre-reading activity used by the teacher was brainstorming activity. Based on the interview to the teacher, this technique was applied in a meeting with the text entitled "Success is A Mind Set". In the process of brainstorming activity, the teacher mentioned a keyword of the topic from the text that will be discussed in the class. This finding is in line with the process of brainstorming activity stated by Wallace (2003), in brainstorming activity the teacher provides keyword of a text that will be read. The students need to mention words and concepts that have association with the keyword provided by the teacher. The teacher mentioned that the purpose of this activity was to make students had a frame of the main topic which will be read.

\section{b. Pre-Teaching Vocabulary}

The teacher did pre-teaching vocabulary in the pre-reading activity. There were two different implementations of this activity. First, in "A Glorious Mongrel" text, there were two stages of the pre-reading activity. The first stage, the teacher took seven words that are related to the text. Then, the teacher provided the scrambled letters of the words. The students should work in group to guess the words. The second stage of the pre-reading activity, the teacher gave the words in the part of the sentences. The students guess the meaning from the sentences. The students made prediction about the information which they would find in the text. Because the text had a lot of advanced words, the 
teacher used the advanced words provided by the text to make the students familiar with the words. Pre-teaching vocabulary may help address unfamiliar words or phrases that can interfere with students' comprehension (Mihara, 2011).

Second, in a text about birth order and personality, the teacher asked the students to make a chart of their personalities. In the process of this activity, the teacher provided a list of characters. The students were divided in groups based on their birth order. There were first born group, middle born group, and later born group. Each group chose 8 characteristics that best represent their group. The teacher's purpose of using this activity was to relate the text to the students' personal experience as a family member. Nunan (2003) explains that background knowledge includes all the experiences that a reader brings to the text. In this case, this is students' life experience as a family member.

\section{c. Pre-Questioning}

The third type of pre-reading activity used by the teacher was prequestioning. The teacher said that this kind of activity was used in the narrative text entitled "Charles". The teacher asked the students to make prediction based on the selected parts of the text. In the process of this activity, the teacher divided the students in small groups. The teacher provided some parts of the materials and distributed it to the groups. The students discussed the scrambled parts in their group.

In the discussion in a smaller group, the students should make questions and predict what they would find in the story, for example the characters in the story. The students would share the information from the part which they had with the other friends who had different parts of the text. They also questioned the information shared by the other friends. In line with Vacca and Vacca (1989) explanation that the teacher can help the students to develop their own questions related to the material which will be read. In this activity, the students created their own questions that would be asked to the other friends

\section{d. Visual Aids and KWL Strategy}

After analyzing the interview result, the researcher could find that the teacher also combine some pre-reading activities. As it is proposed by Hedge (2000), the teachers can combine the prereading activities used. For Steve Jobs graduation speech text, the teacher provided a picture of Steve Jobs. The teacher also asked the students to draw KWL chart, by asking the students what they know and what they want to learn. Vacca and Vacca (1989) state that by asking what students have already known about the text helps them to search their experiences and knowledge which related to the text. Then, by asking what the students need to know helps them activate their background knowledge.

The teacher saw that the students had the physical experiences of having gadgets which were produced by Apple Incorporation. That is the reason why this activity is implemented. This finding is in line with Farrel's (2003) explanation that KWL strategy is one method that will encourage the students to have a personal connection to a reading assignment. The teacher raised the students' curiosity to read the text by asking what they want to learn. The students said they wanted to know Steve Jobs' family life, his love life, and others.

\section{Students' Perception on the Implementation of Pre-reading Activities in Basic Reading II Class}

From the explanation of the questionnaire result, the researcher concluded that the students had positive 
perception on the pre-reading activities used by the teacher in Basic Reading II class. Most of the respondents agreed that they got many advantages from the implementation of pre-reading activities. The result was supported by the fact of the degree of agreement for the statements in the questionnaire. Most of the respondents believed that prereading activities helped them to understand a reading text well. The respondents agreed that pre-reading activities help them to make predictions about that information. The respondents also believed that pre-reading activities could help them imagine the content of the text and remember their experiences related to the topic of the text. The respondents showed positive attitude on the statement that pre-reading activities help them to explore their ideas about the topic of the text. The respondents showed positive response to the statement that pre-reading activities make them curious about the text, being interested and also motivated to read a text. The respondents also agreed with the statement that prereading activities implemented by the teacher make reading activities are fun.

\section{E. CONCLUSION}

The result of the research showed that there were five varieties of the prereading activities implemented by the teacher. They were brainstorming, prequestioning, pre-teaching vocabulary, visual aids and KWL strategy. Among those five, there are two ways in the implementation of pre-teaching vocabulary. Then, there was also a combination of two techniques in a prereading stage. It was the implementation of a picture as visual aid and KWL strategy. The second finding is about students' perception on pre-reading activities implemented by the teacher.
The students' perceptions on pre-reading activities in Basic Reading II class were positive. Most of the respondents believed that pre-reading activities implemented by the teacher helped them to understand reading materials.

\section{REFERENCES}

Ajideh, P. (2006). Schema-theory based considerations on pre-reading activities in ESP textbooks. The Asian EFL Journal, 16, 1-19. Retrieved December 10, 2013, from http://asian-efljournal.com/November_2006_Vol16 _ Art2.pdf

Armbruster, B. B., \& Osborn, J. H. (2002). Reading instruction and assessment. Boston: A Pearson Education Company.

Ary, D., Jacobs, L. C., \& Sorensen, C., (2010). Introduction to research in education (8 ${ }^{\text {th }}$ ed.). Belmont: Wadsworth Group, Thompson Learning.

Baghaei, S. \& Riasati M. J. (2013). An investigation into the relationship between teachers' creativity and students' academic achievement: a case study of Iran EFL context. Middle-East Journal of Scientific Research, 14 (12): 1576-1580. Retrieved June 30, 2014 from http://www.idosi.org /mejsr /mejsr14(12)13/3.pdf

Colorado, C. (2008). Pre-reading activities for ELLs.Retrieved June 30, 2014, from

http://www.fordham.edu/images/a 
cademics/education/rbern/ 5282013 ellactivities.pdf

Farrel, T. S. C. (2003). Planning lessons for a reading class. Singapore: SEAMEO Regional Language Centre.

Hedge, T. (2000). Teaching and learning in the language classroom. New York: Oxford University Press.

Marinak, B. \& Gambrell, L. (2009). Reading motivation: what the research says. Retrieved June 30, 2014, from http://www.readingrockets.org/arti cle/29624

McShane, S. L., \& Glinow, M. A. V. (2005) Organizational behavior 3e. New York: McGraw-Hill Companies Inc.

Mihara, K. (2011). Effects of pre-reading strategies on EFL/ESL reading comprehension. TESL Canada Journal, 28, 51-73. Retrieved December 10, 2013, from http://www.teslcanadajournal.ca/te sl/index.php/tesl/article/ view /1072/891
Navarro, A. M. (2008). Building schema for English language learners.The Education Resources Information Center. Retrieved December 10, 2013, from http://files.eric.ed.gov/fulltext/ ED514335.pdf

Nunan, D. (Ed.). (2003). Practical English language teaching. New York: The McGraw-Hill Companies.

Porter, K. (n.d). Reading: Prereading strategies. Retrieved June 30, 2014, fromhttp://departments.weber.edu /teachall/reading/prereading.html\# top

Vacca, R. T., \& Vacca, J.L. (1989). Content area reading (3rd ed.). New York: Harpe Collins Publishers.

Wallace, C. (2003). Reading. New York: Oxford University Press. 